
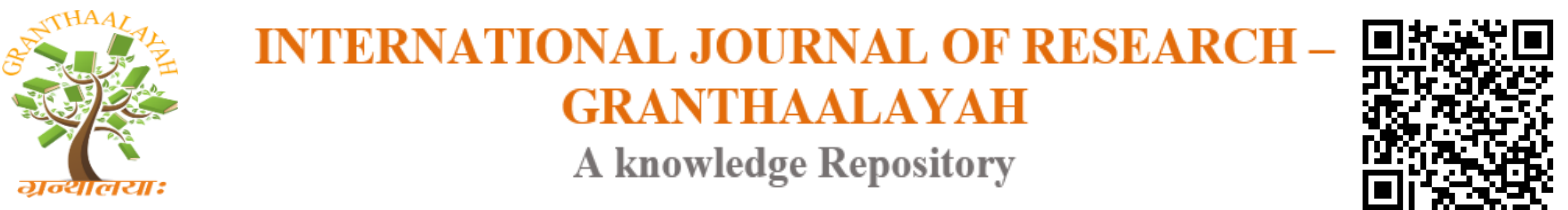

Science

\title{
MYOSTIMULANT EFFECT OF LEAVES OF CASSIA OCCIDENTALIS (CAESALPINIACEAE) ON ISOLATED RABBIT DUODENUM
}

\author{
Mea Arsene ${ }^{* 1}$, Kouakou K.J. ${ }^{2}$, Abo K.J.C. ${ }^{3}$, Nguessan K.J. ${ }^{4}$, Irie Bi J.S. ${ }^{5}$, Kahou Bi G.P. ${ }^{6}$ \\ ${ }^{*} 1,2,3,4,5,6$ Laboratory of Animal Physiology, UFR Biosciences, University of Felix Houphouet-
}

Boigny P.O. Box 582 Abidjan 22; Côte d'Ivoire

DOI: https://doi.org/10.29121/granthaalayah.v5.i4.2017.1824

\section{Abstract}

The fresh leaves of Cassia occidentalis are used in the African pharmacopoeia to treat constipation and malaria. This practice is not recommended for pregnant women. In traditional medicine the fresh leaves used in enema would have abortive properties.

In this work, the aqueous extract of dry leaves of Cassia occidentalis (AECo) is added to the Mc Ewan type physiological solution containing the isolated intestine muscle which is suspended between two shaped stainless steel hooks.

Doses of AECo less than 10-2 $\mathrm{mg} / \mathrm{ml}$ have no significant effect on duodenal contractions.

For doses between 10-1 $\mathrm{mg} / \mathrm{ml}$ and $4 \mathrm{mg} / \mathrm{ml}$, baseline amplitude and tone increased from $10.12 \pm 4.02 \%$ ( $\mathrm{P}<0.005)$ to $55.37 \pm 3.23 \%$ ( $\mathrm{P}<0.001)$.

Indeed, at doses of 1,2 and $4 \mathrm{mg} / \mathrm{ml}$, AECo leads to significant increases in the amplitude of the contractions which pass successively from $0.32 \pm 0.09 \mathrm{mN}, 0.41 \pm 0.07 \mathrm{mN}$ to $0.49 \pm 0,13$ $\mathrm{mN}(\mathrm{P}<0.001)$.

Let a variation in the amplitude of the rhythmic contractions of the duodenum of $30.82 \pm 3.07 \%$, $44.32 \pm 2.47 \%$ and $55.37 \pm 4.23 \%$, respectively. An increase in the amplitude and tone of rhythmic contractions is in a dose-dependent manner.

The myostimulant effect is characterized by the increase of the rhythm and the amplitude of isolated intestine muscle.

The effect of AECo is partially suppressed by atropine. This suggests the presence of muscarinic cholinergic compounds in this aqueous extract.

Keywords: Cassia Occidentalis; Myostimulant; Duodenal Muscle; Atropine.

Cite This Article: Mea Arsene, Kouakou K.J., Abo K.J.C., Nguessan K.J., Irie Bi J.S., and Kahou Bi G.P.. (2017). "MYOSTIMULANT EFFECT OF LEAVES OF CASSIA OCCIDENTALIS (CAESALPINIACEAE) ON ISOLATED RABBIT DUODENUM." International Journal of Research - Granthaalayah, 5(4), 301-310. https://doi.org/10.29121/granthaalayah.v5.i4.2017.1824. 


\section{Introduction}

Originally from South America (Ake-Assi, 1983), Cassia occidentalis (Caesalpiniaceae) has become a pantropical species thanks to its great capacity for expansion. In West Africa and particularly in Senegal and Côte d'Ivoire, it is found around villages and in fields where it can be a formidable weed of crops. This is one of the ten most harmful weeds in cotton crops (Higgins et al., 1985).

In Africa, traditional medicines play an important role in the treatment of various pathologies (Pousset, 2006). Cassia occidentalis (Caesalpiniaceae) is widely known in the pharmacopoeia because of the numerous virtues attributed to it. The whole plant (fruits, flowers, leaves, stems and roots) is used internally or externally in a wide variety of ways. The leaves and the whole plant are used for the treatment of sterility, venereal diseases, hepatitis, rheumatism and burns. Fresh leaves and roots macerated in water are used against respiratory tract diseases. Roasted seeds of Cassia occidentalis are used as an anti-diabetic in combination with the barks of dried trunks of terminalia macroptera and Tapinantus sp (parasite of Combretum nigricans). The antimalarial action of Cassia occidentalis is sufficiently pronounced to replace quinine in the treatment of malaria (Fortin et al., 1990)

Aqueous extracts of the stems and leaves of Cassia occidentalis are effective on sarcoma 180 (Kerharo and Adam, 1974). According to Kante, (1982), the macerated leaves of Cassia occidentalis are given to drink to the patients of asthma. In Benin, (West Africa) Adjanohoun et al., (1989) reported the use of Cassia occidentalis seeds in the treatment of diarrhea. This plant is part of the stimulants of the smooth musculature. At high doses, there is a pronounced stimulation which would favor contractions at the time of delivery, hence its contraindication in pregnant women (Kerahoro and Adam, 1974).

\section{Materials and Methods}

\subsection{Plant Material}

The plant material consists of the leaves of Cassia occidentalis (Caesalpiniaceae) harvested in Abobo, in the district of Abidjan (Côte d'Ivoire) in August 2016. It was identified at the National Center of Floristics (CNF) of University Felix Houphouët-Boigny (UFHB) where a sample was deposited.

\subsubsection{Preparation of the Aqueous Extract of the Leaves of Cassia Occidentalis}

Hundred grams of crushed dried petals are boiled with one (1) liter of distilled water in a Pyrex jar for ten minutes. The decoction is cooled and filtered successively on cotton wool to retain the important dimensions of impurities; then on Whatman filter paper to the impurities of small dimensions by the method revised by Abo et al. (2016). The aqueous filtrate is dehydrated in the oven at $40^{\circ} \mathrm{c}$.

A hydrophilic fine powder purple red color is obtained. A stock solution with a quantity of this powder is prepared. From this stock solution, test solutions of different concentrations are made. 


\subsubsection{Characterization of Some Secondary Metabolites of the Leaf Extract}

The secondary metabolites are characterized by characterization tests of the large groups of chemical compounds contained in the aqueous extract of Cassia occidentalis (Caesalpiniaceae) leaves. The detection of these compounds is based on the principle that they induce chemical reactions in the presence of suitable reagents (Wagner and Bladt, 2001). These tests are carried out in test tubes in accordance with the analytical techniques described by Lazureki et al. (1966), Bekro et al., (2007) and Mea et al. (2016). For these tests, a solution of Cassia occidentalis is prepared by dissolving $5 \mathrm{~g}$ of AECo in $50 \mathrm{ml}$ of distilled water.

\subsection{Animal Material}

The rabbit of the specie Oryctolagus cuniculus (Leporideae) were brought from farms near Abidjan (Côte d'Ivoire). They were acclimated to laboratory conditions in the Biology and Sciences United Formation (Laboratory of Animal Physiology) for weeks to regulate and harmonize their physiological states. They were kept at constant temperature $\left(25 \pm 3^{\circ} \mathrm{c}\right)$ with 50 $55 \%$ of humidity and a photoperiod of 12 hours of daylight and 12 hour of darkness. They are fed ad libitum with pellet and water. They were carefully screened and confirmed to be healthy during the procedures were conducted in accordance with the guiderlines for Care and Use of Laboratory Animals published by the National Institutes of Health.

\subsection{Organ Preparation}

The equipment that allows the recording of contractions of the intestine is composed of a tank with a bain-marie in which a smaller tank contains the isolated intestine fragment. This last tank is connected by coils embedded in the water bath a flasks, one of which contains the physiological solution of reference. Each coil communicates with a tap has multiple selection paths. The physiological solution in which the intestine bath is oxygenated thanks to an air bubble generator and its temperature is maintained at $38 \pm 1^{\circ} \mathrm{C}$ as described by Mea et al. (2016). A permanent return to reference physiological solution cleans the organ (back to normal) before moving to the next test concentration. The isolated intestine muscle is suspended between two sharped stainless steel hooks as describe by Konan et al. (2011). The rhythmic contractions are recorded on paper.

\subsection{Physiological Solutions and Pharmacodynamic Substances}

\subsubsection{Mac Ewan Type Solution}

The salts used in Mac Ewan type physiological solution are: $\mathrm{NaCl}(80 \mathrm{~g} / 1), \mathrm{KCl}(20 \mathrm{~g} / 1), \mathrm{CaCl}_{2}$ (20 g / 1), $\mathrm{PO}_{4} \mathrm{H}_{2} \mathrm{Na}(15 \mathrm{~g} / \mathrm{l}), \mathrm{CO}_{3} \mathrm{HNa}$ and $\mathrm{MgCl}_{2}(10 \mathrm{~g} / \mathrm{l})$ added in water (QSP). Anhydre glucose is added to the solution before the test.

\subsubsection{Pharmacodynamic Substances}

The reference chemical used is atropine (ATR) (Prolabo, France). 


\subsection{Statistical Analysis}

Results are analyzed by analysis of variance ANOVA multiple comparison test of TukeyKramer. $\mathrm{P}<0.05$ is considered significant. The values are presented as average (mean), followed by the standard error of the mean (SEM).

The curves are drawn through GraphPadprism5 (San Diego CA USA) biological software.

\section{Results}

\subsection{Identification of the Phytoconstituents in the Aqueous Extract of Cassia Occidentalis}

The phytochemical screening of the aqueous extract of Cassia occidentalis leaves (AECo) makes it possible to identify certain groups of chemical substances in this extract. This study reveals in the AECo the presence of sterols and polyterpenes, polyphenols, flavonoids, gallic tannins, alkaloids and saponosides. On the other hand, catechic tannins and dogs are absent in this extract of Cassia occidentalis leaves. Table 1 summarizes the results of this phytochemical study.

Table 1: Phytochemical screening of the aqueous extract of leaves of Cassia occidentalis

\begin{tabular}{|c|c|c|c|}
\hline \multicolumn{2}{|c|}{ Chemical compounds } & Reagents & Results \\
\hline \multicolumn{2}{|c|}{ Sterols and polyterpenes } & Liebermann & + \\
\hline \multicolumn{2}{|c|}{ Polyphenols } & Iron chloride & + \\
\hline \multicolumn{2}{|c|}{ Flavonoids } & Cyanidin & + \\
\hline \multirow{2}{*}{\multicolumn{2}{|c|}{ Saponosides }} & Strong agitation & + \\
\hline & & Dragendorff & + \\
\hline \multicolumn{2}{|c|}{ Alkaloids } & Bouchardat & + \\
\hline & Gallic & Hydrochloric acid & + \\
\hline Tannins & Catechics & Stiasny & - \\
\hline \multicolumn{2}{|c|}{ Quinonic substances } & Borntraegen & - \\
\hline
\end{tabular}

$+:$ Presence of the desired compound (positive test)

-: absence of the desired compound (negative test)

\subsection{Dose-Response Effects of Aqueous Extract of Cassia Occidentalis on Rabbit Isolated Duodenal Muscle}

Figure 1 shows typical recordings of the effects of aqueous extract of Cassia occidentalis leaf on rabbit isolated duodenal muscle contractions at concentrations between $10^{-2}$ and $3 \mathrm{mg} / \mathrm{ml}$.

Doses of AECo less than $10^{-2} \mathrm{mg} / \mathrm{ml}$ have no significant effect on duodenal rhythmic contraction which is at $0.32 \pm 0.12 \mathrm{mN}$. 
But the $10^{-2}$ and $10^{-1} \mathrm{mg} / \mathrm{ml}$ concentrations results in a brief and transient decrease followed by a dose-dependent increase in the amplitude of rhythmic contractions of the duodenum at $0.35 \pm 0.40$ and $0.37 \pm 0.29 \mathrm{mN}$ (Figure $1 \mathrm{~B}$ and $1 \mathrm{C}$ )

With doses of AECo varying from 1 to $3 \mathrm{mg} / \mathrm{ml}$, an increase in the basic tone and amplitude of the contractions of the duodenal smooth muscle appears.

Indeed, at concentrations of 1,2 and $3 \mathrm{mg} / \mathrm{ml}$ of AECo, the tone and amplitude of contractions increased from $0.32 \pm 0.09 \mathrm{mN}$ to $0.0 .41 \pm 0.07,0.46 \pm 0.13$ and $0.49 \pm 0.32 \mathrm{mN}(\mathrm{P}<0.001)$.

Doses of $10^{-2}$ and $10^{-1} \mathrm{mg} / \mathrm{ml}$ resulted in variations in the amplitude of rhythmic contractions of $10.12 \pm 4.02 \%(\mathrm{P}<0.005)$ and $17.00 \pm 2.94 \%(\mathrm{P}<0.001)$.

The doses of 1,2 and $3 \mathrm{mg} / \mathrm{ml}$ varied the amplitude of the rhythmic contractions of the duodenum by $30.82 \pm 3.07 \%, 44.32 \pm 2.47 \%$ and $55.37 \pm 3.23 \%(n=5)$ respectively (Figure 2 )

A

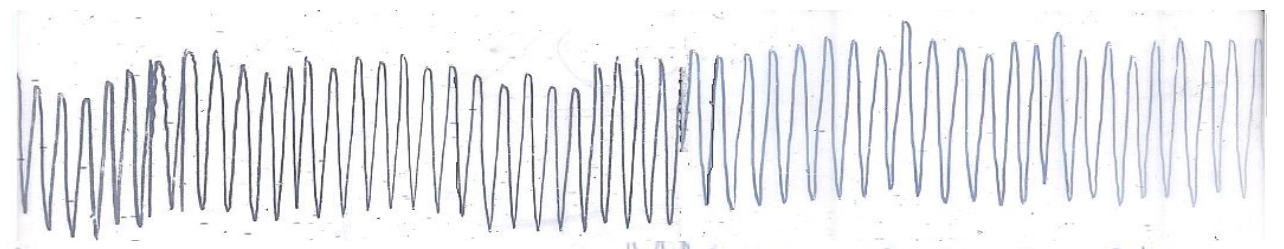

B

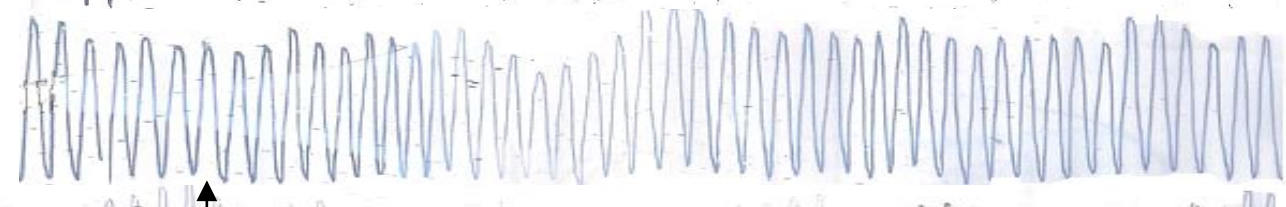

C



D

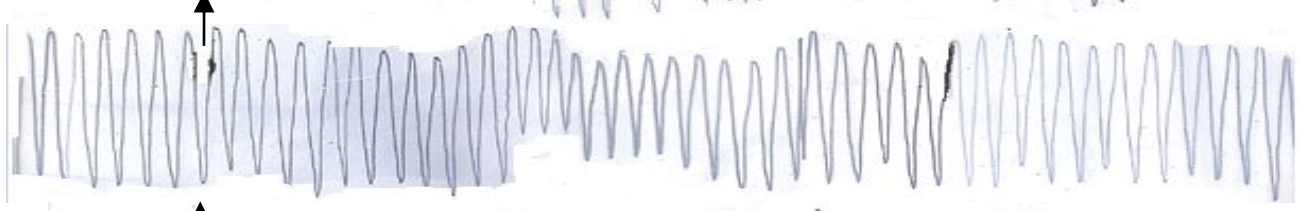

$\mathrm{E}$
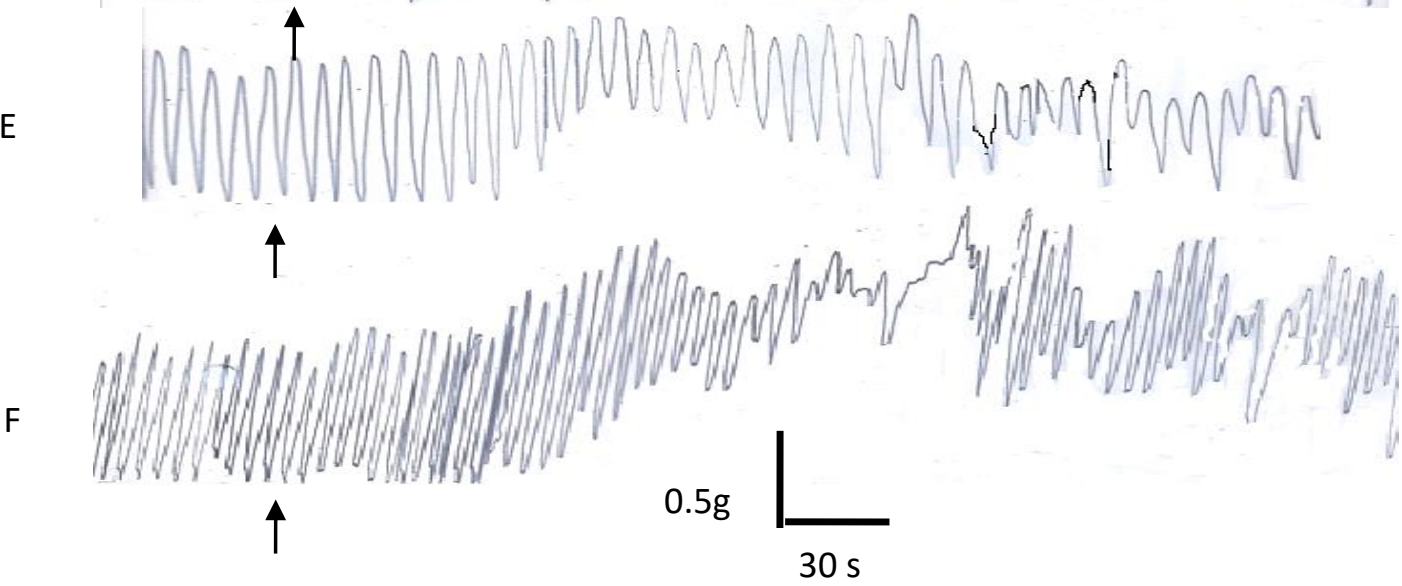

Figure 1: Dose-response effects of aqueous leaf extract of Cassia occidentalis (AECo) on the contractile activity of the isolated rabbit duodenum 
A: normal recording

$\mathrm{B}$ : normal recording followed by the effect of AECo $10^{-2} \mathrm{mg} / \mathrm{ml}$

C: normal recording followed by effect of AECo $10^{-1} \mathrm{mg} / \mathrm{ml}$

D: normal recording followed by effect of AECo $1 \mathrm{mg} / \mathrm{ml}$

$\mathrm{E}$ : normal recording followed by effect of AECo $2 \mathrm{mg} / \mathrm{ml}$

F: normal recording followed by effect of AECo $3 \mathrm{mg} / \mathrm{ml}$

Table 2: Evolution of the percentage of the rhythmic contraction as a function of the dose of

\begin{tabular}{lll}
\multicolumn{2}{c}{ AECo } \\
\hline Dose of AECo $(\mathbf{m g} / \mathbf{m l})$ & MEAN (Percentage) & SEM \\
\hline $10^{-3}$ & 0 & 0.00 \\
$10^{-2}$ & 10.12 & 4.02 \\
$10^{-1}$ & 17.00 & 2.94 \\
1 & 30.82 & 3.07 \\
2 & 44.32 & 2.47 \\
3 & 55.37 & 3.23 \\
\hline
\end{tabular}

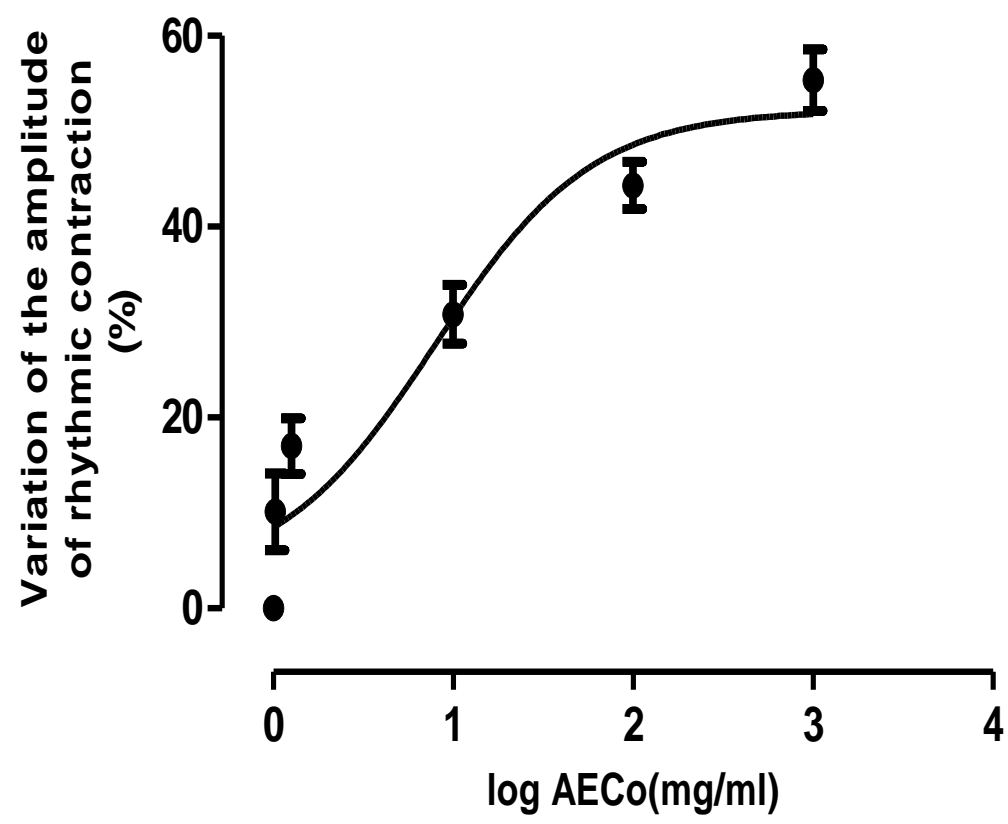

Figure 2: Curve of increasing in amplitude of the rhythmic contraction of the duodenal muscle

\subsection{Interaction between (AECo) and Atropine on Contractions of Rabbit Isolated Duodenum}

In this experiment, AECo interacts with atropine at a dose of $10^{-6} \mathrm{mg} / \mathrm{ml}$ and $10^{-5} \mathrm{mg} / \mathrm{ml}$. These doses don't affect the normal contractions of the duodenal fragment. 
Thus, AECo, at a dose of $3 \mathrm{mg} / \mathrm{ml}$, induces an increase in basal tone and amplitude of the rhythmic contractions of the duodenum of $0.50 \pm 3.23 \mathrm{mN}$ (figure 3A). These effects persist for a long time before a gradual return of contractions to normal.

When AECo at a dose of $3 \mathrm{mg} / \mathrm{ml}$ is added to the physiological medium containing $10^{-6} \mathrm{mg} / \mathrm{ml}$ of atropine, the increase in basal tone is brief and transient (figure 3B).

The basic tone and amplitude of contractions quickly return to normal after a few seconds.

When AECo at $3 \mathrm{mg} / \mathrm{ml}$ is added to the medium containing atropine at $10^{-5} \mathrm{mg} / \mathrm{ml}$, baseline tone increases transiently. Then gradually, the amplitude of rhythmic contractions and basic tone return to normal and decreases subsequently (figure 3C).

A

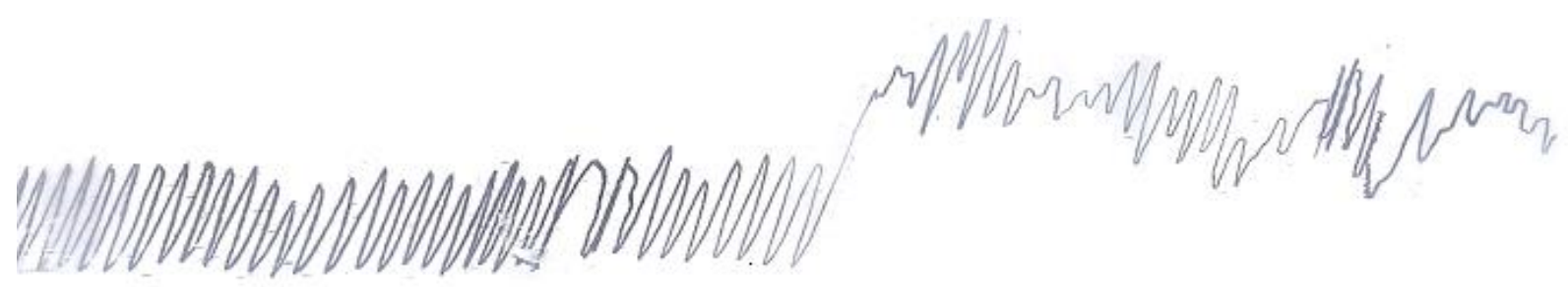

B

$\mathrm{C}$

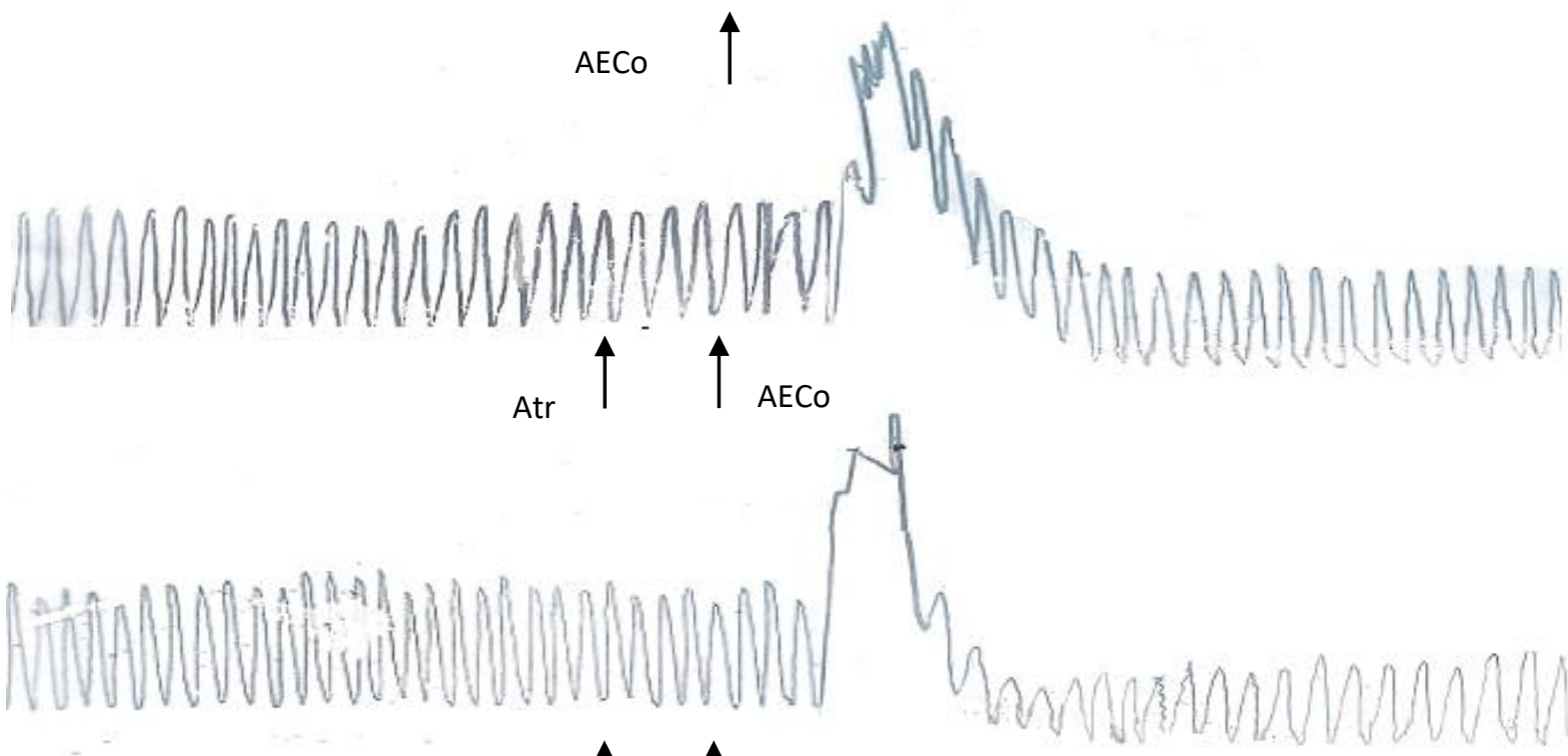

$0,5 \mathrm{~g}$

Atr $\uparrow \quad \uparrow_{\text {AECo }}$

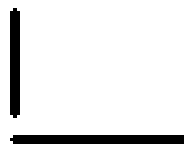

$30 \mathrm{~s}$

Figure 3: AECo-Atropine interaction on the contractile activity of the rabbit isolated duodenum 
A: Control recording (before arrow) and effects of AECo $3 \mathrm{mg} / \mathrm{ml}$

B: Control recording (before the 1st arrow), effects of atropine at $10^{-6} \mathrm{mg} / \mathrm{ml}$ (1st arrow) followed by AECo at $3 \mathrm{mg} / \mathrm{ml}$ (2nd arrow).

$\mathrm{C}$ : control recording (before 1st arrow), effects of atropine at $10^{-5} \mathrm{mg} / \mathrm{ml}$ (1st arrow) and AECo $3 \mathrm{mg} / \mathrm{ml}$ (2nd arrow).

\section{Discussion}

The aqueous extract of Cassia occidentalis (Cesalpiniaceae) contains gallic tannins, alkaloids, sterols and polyterpenes, polyphenols, flavonoids and saponosides.

The richness of this plant in secondary compounds with various pharmacological effects explains its "quenching" effect which is observed with a transient decrease in contractions followed by an increase in their amplitude (Clarke, 2008).

Increases the amplitude of the rhythmic contractions of the duodenal muscle is similar to the effects of Swartzia madagarensis (Cesalpiniaceae) aqueous extracts on rabbit intestinal contractile activity described by Traore et al. (2003) and Sesamum radiatum on taenia caeci by Konan et al. (2011).

The increase in the amplitude of the contractions induced by the aqueous extract of Cassia occidentalis shows that this extract contains myostimulating compounds.

Acetylcholine gives similar effects by stimulating cholinergic receptors of muscarinic types on smooth muscle structures (Eglen et al. 1994).

Atropine is a competitive inhibitor of muscarinic cholinergic receptors on the smooth muscle (Goodman, 2010). In this work, atropine inhibits partially the effect induced by AECo.

This shows that the effects of AECo result partially from the stimulation of muscarinic cholinergic receptors. The aqueous extract of Cassia occidentalis therefore contains muscarinic cholinergic substances.

The $\mathrm{M}_{3}$ muscarinic receptors are located at many places in the body. They are located in the smooth muscles of the blood vessels, as well as in the lungs. Peripheral M3Rs play a key role in mediating the stimulatory actions of acetylcholine on smooth muscle and glandular tissues (Caulfield and Birdsall, 1998; Eglen, 2005; Wess et al., 2007). Because the $\mathrm{M}_{3}$ receptor is $\mathrm{G}_{\mathrm{q}^{-}}$ coupled and mediates an increase in intracellular calcium, it typically causes contraction of smooth muscle (Moro et al., 2011).

The effects would therefore result from an increase in intracellular calcium caused by the extract, similar to cholinergic substances.

\section{Conclusion}

The richness of the aqueous extract in chemical compounds with known therapeutic effects could explain the use of Cassia occidentalis (Caesalpiniaceae) in traditional African medicine to treat many pathologies (much pathology). 


\section{Acknowledgement}

This work is a subject of research for a Master in Phytotherapy that I have framed. There was no intervention by any organization. The work was funded and carried out at our expense. There is therefore no conflict of interest to this effect.

\section{References}

[1] Abo K. J. C., Kouakou K.L. and Yapo A. (2016) HYPOTENSIVE AND ANTIHYPERTENSIVE EFFECTS OF TOTAL AQUEOUS EXTRACT OF JUSTICIA SECUNDA VALM M. (ACANTHACEAE) IN RABBITS. Intern. Journal of sciences and Research. Vol. 5(5): 14551462.

[2] Adjanohoun E. (1989) CONTRIBUTION AUX ETUDES ETHNOBOTANIQUES ET FLORISTIQUES AU BENIN ET A PARIS. ACCT MEDECINE TRADITIONNELLE ET PHARMACOPEE. Paris, $85 \mathrm{p}$.

[3] Ake-Assi, L. (1983) QUELQUES VERTUS MEDICINALES DE CASSIA OCCIDENTALIS L. BOTHANIA, 14(3-4):

[4] 617-620.

[5] Bekro Y., Bekro J., Boua B.B., Tra B. F. and Ehile E. E.(2007) ETUDE ETHNOBOTANIQUE ET SCREENING PHYTOCHIMIQUE DE CAESALPINIA BENTAMIANA (BAILL). HEREND ET ZARRUCCHI (CAESALPINIACEAE). Sci Nat , $4:$ 17-25.

[6] Caulfield M.P. and Birdsall N.J. (1998) INTERNATIONAL UNION OF PHARMACOLOGY. XVII. CLASSIFICATION OF MUSCARINIC ACETYLCHOLINE RECEPTORS. Pharmacol Rev 50:279-290

[7] Clarke S. (2008) Essential CHEMISTRY FOR AROMATHERAPY, SECOND EDITION. Churchill Livinston, Elsevier, 2008: 128-129

[8] Eglen R.M, Reddy H, Watson N. and Challiss RA.(1994) "MUSCARINIC ACETYLCHOLINE RECEPTOR SUBTYPES IN SMOOTH MUSCLE.". Trends Pharmacol. Sci. 15 (4): 114-9.

[9] Eglen R.M. (2005) MUSCARINIC RECEPTOR SUBTYPE PHARMACOLOGY AND PHYSIOLOGY. Prog Med Chem 43:105-136.

[10] Fortin D., Lo M. and Maynart G. (1990) MEDICINAL PLANTS OF THE SAHEL. CECI/ ENDA. MONTRÉAL , Dakar, 280 p.

[11] Goodman E. Ketchum J. and Kirby R. (2010) HISTORICAL CONTRIBUTIONS TO THE HUMAN TOXICOLOGY OF ATROPINE. Eximdyne. p. 120. 2010

[12] Higgins. J.M., Walker. R.H. and Whitwell T. (1985) COFFEE SENNA (CASSIA OCCIDENTALIS) IN COMPETITION WITH COTTON (GOSSYPIUM BIRSUTUM). Weed Science 34: 52-56. 1985

[13] Kanté M. (1982) PLANTES MEDICINALES DE COTE D'IVOIRE. CONTRIBUTION A L'ETUDE DU CASSIA OCCIDENTALIS L. (CAESALPINIACEAE). Thèse Pharmacie., Dakar (Sénégal) 63p. 1982

[14] Kerharo, J. and Adam, J.G. (1974) LA PHARMACOPEE SENEGALAISE TRADITIONNELLE. PLANTES MEDICINALES ET TOXIQUES. Ed, Vigot Frere. Paris. 1974

[15] Konan B.A., Amonkan K.A., Ahui B.M.L., Bouaffou K.G.M, Kouakou K.L., Kpahé Z.F. and Datté Y.J. (2001) MYOSTIMULATING EFFECT OF SESAMUM RADIATUM AQUEOUS LEAF EXTRACT IN ISOLATED GUINEA-PIG TAENIA CAECI CONTRACTIVE ACTIVITY. Afr. J. Tradit. Complement Altern. Med. 8 (4): 377-385

[16] Mea A., Abo J.C. and Kassi Y.T. (2016) STIMULATING EFFECT AND MECHANISM OF ACTION OF AN AQUEOUS EXTRACT OF HIBISCUS SABDARIFFA (MALVACEAE) ON THE INTESTINAL MUSCLE OF THE RABBIT. Intern. Journ. of Inform. Res. and Rev. 03(12): 3378-3384. 
[17] Moro C, Uchiyama J. and Chess-Williams R (2011). "UROTHELIAL/LAMINA PROPRIA SPONTANEOUS ACTIVITY AND THE ROLE OF M3 MUSCARINIC RECEPTORS IN MEDIATING RATE RESPONSES TO STRETCH AND CARBACHOL". Urology. 78 (6): 1442.e9-15.

[18] Pousset J. L. (2006) TRADITIONAL MEDICINES IN AFRICA. Med Trop, 66 : 606-609.

[19] Traore F., Soro T.Y., Abo J.C. and Ehouman E. (2003) EFFETS PHARMACOLOGIQUES DE SWARTZIA MADAGASCARIENSCIS (CAESALPINIACEAE) SUR L'ACTIVITE CONTRACTILE INTESTINALE DE LAPIN. Rev. Med. Pharm. Afr., 18: 85-98

[20] Wagner H. and Bladt S. (2001) PLANT DRUG ANALYSIS. Springer, 368 p.

[21] Wess J, Eglen RM and Gautam D (2007) MUSCARINIC ACETYLCHOLINE RECEPTORS: MUTANT MICE PROVIDE NEW INSIGHTS FOR DRUG DEVELOPMENT. Nat. Rev. Drug Discov. 6:721-7337

*Corresponding author.

E-mail address: mearsene@gmx.fr 